\title{
O mecanismo educacional nos romances A Cidade e os cachorros de Mario Vargas Llosa, Manhã submersa de Vergílio Ferreira e O Ateneu de Raul Pompéia
}

\author{
Ana Carolina Rhormens de Santana* \\ Caio Gagliardi ${ }^{* *}$
}

Os romances A Cidade e os cachorros de Mario Vargas Llosa, Manhã submersa de Vergílio Ferreira e O Ateneu de Raul Pompéia guardam um aspecto comum, a trajetória de formação de seus jovens protagonistas em meio ao confinamento de internatos escolares, os quais, embora possuam regras e métodos educacionais próprios, revelam-se, com o tempo, variações de um mesmo sistema de controle disciplinar.

Acerca do mecanismo educacional implementado no internato de $O$ Ateneu, Quintale Neto (2007, p. 106) adverte que o objetivo era preparar os alunos "para suportar qualquer adversidade com uma dureza sobre-humana”. É sintomático que o protagonista Sérgio, em seu primeiro contato com o colégio, durante uma visita pré-matrícula, assista a uma apresentação de ginástica, que representa a "associação da força física e do espírito militar com a preparação para que os fortes vençam a luta que é a vida" (Quintale Neto, 2007, p. 107). Nesse capítulo, a característica "militar", segundo as regras do Ateneu, é associada aos elementos "força física", "saúde", "farda negra" e "manobras perfeitas" (Pompéí, 2008, p. 50).

De forma análoga, em A Cidade e os cachorros, no momento do ingresso dos protagonistas no colégio militar Leoncio Prado, que faz vezes de quartel, o capitão explica que "o espírito militar se compõe de três elementos simples: obediência, trabalho e coragem" (LLOSA, 1963/2007, p. 48). Em Manhã submersa, por sua vez, os seminaristas, ao desembarcarem do comboio, são recepcionados pelas "ordens

\footnotetext{
Mestra na área de Literatura Portuguesa pelo Departamento de Letras Clássicas e Vernáculas da Universidade de São Paulo (USP), São Paulo, SP, Brasil. E-mail: carolrhormens@uol.com.br.

* Professor Doutor na área de Literatura Portuguesa do Departamento de Letras Clássicas e Vernáculas da Universidade de São Paulo (USP), São Paulo, SP, Brasil. Realizou Pós-Doutorado no Dipartimento di Studi Europei, Americani e Interculturali da Università degli Studi di Roma "La Sapienza" (UNIROMA), Roma, RM, Itália, e no Departamento de Teoria Literária e Literatura Comparada da Universidade de São Paulo (USP), São Paulo, SP, Brasil. E-mail: caiogagliardi@gmail.com.
} 
chicoteadas" (FERREIRA, 1954/2008, p. 18) dos padres. No primeiro dia de aula, a postura de António é recriminada, "alguém me repuxou a cabeça várias vezes [...] até ma deixar, por fim, na posição correcta" (FERREIRA, 1954/2008, p. 21). Os padres exigem obediência da "massa" (FerReIRA, 1954/2008, p. 18) ao "Regulamento", cuja rotina abrange, além do programa escolar laico, um amplo cronograma religioso. Assim, a palavra-chave nos três casos é "disciplina".

\section{A imposição de uma disciplina militarista}

Michel Foucault (1987, p. 153), em Vigiar e Punir, ao traçar a evolução dos procedimentos disciplinares na sociedade moderna, tendo como modelo o soldado militar, afirma que "a disciplina 'fabrica' indivíduos; ela é a técnica específica de um poder que toma os indivíduos ao mesmo tempo como objetos e como instrumentos de seu exercício". Conclui que a disciplina tem o poder de "adestrar". Para isso, há algumas medidas simples: enclausuramento; vigilância panóptica; controle das atividades, dada a administração de um horário rígido; exercícios exaustivos, repetitivos e graduados; combinação das forças individuais, a fim de formar um corpo uniforme; e leis próprias de premiação e punição. As medidas disciplinares, então, não consistem num método educacional em si, mas num mecanismo de coerção para transformar indivíduos em "corpos dóceis", obtendo um todo homogêneo e alienado, uma "massa obediente", sem capacidade de autoafirmação e diferenciação.

É essa disciplina militarista que está presente na rotina dos jovens dos três romances. A sua imposição fica bem declarada durante as cerimônias institucionais, como passeios e festas. Isto porque, como mostra Goffman (2010, p. 86), em $\mathrm{Ma}$ nicômios, prisões e conventos, a exibição institucional, atribuindo um "caráter de realidade pública ao mundo interior", faz com que os dirigentes se esforcem para transmitir uma imagem "adequada" do estabelecimento aos visitantes e, então, intensifiquem a rigidez do respeito às regras. Em Manhã submersa, por exemplo, por ocasião de um passeio, o narrador comenta: "íamos passar por uma aldeia, e parámos por isso para nos pormos na forma e atravessá-la depois em silêncio, como era do regulamento" (FerReirA, 1954/2008, p. 111), deixando entrever que a apresentação dos internados a olhos estranhos é extremamente controlada.

Em O Ateneu, na Bienal dos Prêmios, da qual Sérgio participa, "os alunos entravam fardados [...], fazendo tremer o edifício todo de carpintaria. Aristarco veio à porta, $[\ldots]$ majestade dominadora da presença [...]. Os rapazes olhavam com o prazer do soldado que se orgulha do comandante." (PoMPÉIA, 1888/2008, p. 238). O olhar da plateia e a atitude austera do dirigente, uma dupla via coercitiva, moldam a forma de agir dos internados, os quais passam a corresponder às expectativas, tornando-se uma massa obediente.

O mesmo modus vivendi se repete em A Cidade e os cachorros durante a caminhada para o exercício de campanha. Os apitos, gritos e ordens dos oficiais fazem os cadetes agirem depressa. "O alarido que vinha do rancho [dos oficiais] cresceu 
e, um momento depois, os cadetes começaram a sair a toda. [...] apertavam os cinturões, amarravam os cadarços dos coturnos, ajeitavam os gorros, tiravam o pó dos fuzis, verificavam a bandoleira" (LLOSA, 1963/2007, p. 168). Segundo Foucault (1987, p. 126), para transformar um conjunto de indivíduos em um "corpo dócil", é preciso "exercer sobre ele uma coerção sem folga, de mantê-lo ao nível mesmo da mecânica - controlando movimentos, gestos, atitudes, rapidez".

Ao recorrer aos pressupostos teóricos de Goffman (2010) e Foucault (1987), convém esclarecer que ambos tratam dos mecanismos de funcionamento de unidades prisionais, porém suas abordagens diferem entre si. Goffman está interessado em como o indivíduo se comporta e reage em uma forma de interação social específica, moldada pela estrutura física fechada da instituição total em que ele se encontra. Foucault está interessado em percorrer o processo histórico de mudança das prisões, a fim de analisar como isso resultou em uma política das sociedades modernas, a política do "corpo dócil". Segundo Almeida (2010), enquanto Foucault pensa as regularidades da instituição prisional a partir de relações de poder e de dominação, Goffman as pensa a partir das formas de interação. Portanto, Foucault adota uma perspectiva macrossociológica, usa os mecanismos institucionais para tratar de algo externo à instituição, e Goffman, microssociológica, já que fica atento aos detalhes da vida dentro dessa mesma instituição. Os próprios termos usados resumem a diferença entre eles. Goffman analisa a trajetória do self, enquanto Foucault dos corpos dóceis. Isto porque Goffman rejeita "regras de método", não vê o indivíduo como um simples produto da internação, mas como alguém que percorre um caminho único dentro desse meio. Por outro lado, como ainda descreve Benelli (2004, p. 245), "Foucault nos apresenta uma sociedade disciplinar sem brechas, na qual a resistência ao poder parece impossível”. É exatamente essa teoria disciplinar determinista, que desconsidera a perspectiva individual do interno, que os dirigentes dos três colégios internos, o Seminário católico, o Ateneu e o Leoncio Prado, empregam.

- Nome e seção - diz o tenente. [...] - Alberto Fernández, quinto ano, primeira seção. - Fale logo - diz o tenente -, fale logo. - Acho que estou doente, meu tenente. Quer dizer, da cabeça, não do corpo. Tenho pesadelos todas as noites. [...] - E desde quando eu sou padre [...]?! Vá pedir conselhos morais ao seu confessor ou à sua mãe! (LlosA, 1963/2007, p. 19).

Esses "educadores" não cumprem sua função. O tenente não está ali disposto a dar conselhos, a preocupar-se com os problemas individuais dos alunos (a quem nem é dada a chance de se expressar), mas para assegurar que sejam adestrados. Tanto é que pouco importa a fisionomia, o aluno passa a ser um número. Essa perda da identidade e do poder de alternância de papéis é um dos principais aspectos da etapa que Goffman (2010) chama de "morte civil" dos confinados. Em O Ateneu, Sérgio sente o primeiro sinal de perda da capacidade de diferenciação na ocasião da matrícula, quando o diretor Aristarco lhe impõe o corte de cabelo. 
Supondo que a doutrina disciplinar, descrita por Foucault, aprovasse a ordem do diretor como medida para serialização dos corpos, Goffman agiria de modo contrário, julgando esta como mais uma das mortificações sentidas pelo self dentro da instituição totalizante. Comparando as duas correntes teóricas, poderia se concluir que, enquanto Foucault vê a situação pela perspectiva dos dirigentes, Goffman a analisa através da vivência do internado. E, além da atribuição de número e do corte de cabelo, vários outros processos de admissão formal são empregados na "morte civil", como despir, dar banho, distribuir roupas da instituição, dar instruções quanto a regras, designar um local para o internado etc. (GofFMAN, 2010). Em Manhã submersa, assim que adentram no casarão, um padre "ia separando as divisões [de seminaristas] para as respectivas camaratas" (FERREIRA, 1954/2008, p. 9), onde estava "marcada a cama de cada um". Logo após isso, o narrador conta: "fomos à capela e nos despimos, com um cerimonial esquisito, antes de dormirmos" (FerreIrA, 1954/2008, p. 9). No dia seguinte, acordam com a sineta e, à pressa, todos devem se vestir adequadamente, formando aquela "confusão de fatos pretos" (Ferreira, 1954/2008, p. 18).

\section{As leis próprias da instituição: premiações e punições}

Goffman (2010, p. 50) chama a atenção para o fato de existirem "regras da casa", ou seja, "um conjunto explícito e formal de prescrições e proibições que expõe as principais exigências quanto à conduta do internado". Essas regras acabam por especificar a rotina das instituições totais. São privilegiados aqueles que se mantém dentro do que se julga "bom comportamento". Porém, em A Cidade e os cachorros, por mais que se afirme que o conjunto de prescrições e proibições é bem delimitado no regulamento e na rotina do Leoncio Prado, revela-se, aos poucos, a arbitrariedade desse sistema. Ricardo Arana, que é punido no lugar de outros colegas, por exemplo, reclama: "Não é justo. O serrano sai todo sábado, feliz da vida. E nós aqui dentro, por culpa dele" (LLOSA, 1963/2007, p. 119).

Em O Ateneu, Sérgio também comenta que o Livro das Notas é "redigido ao sabor da justiça suspeita dos professores" (POMPÉIA, 1888/2008, p. 94). A leitura do Livro, feita pelo diretor em pessoa todas as manhãs, revelando-se um hábito institucional, ditava o comportamento dos estudantes, seja para o esforço dos alunos mais aplicados, seja para o surgimento dos arranjos secundários dos espertos, mas verifica-se sempre uma tentativa de manter reputações. Esclarece o narrador extradiegético: "Fosse como fosse, certo é que, com bilhetes de boa nota, compravase uma saída, e isto era o importante, como nos países das más finanças: desde que o papel tem curso, de que vale o valor?" (PompÉIA, 1888/2008, p. 120). Em Manhã submersa, também existia o Livro das Notas, cuja leitura semanal, sob o olhar dos outros, contribui para o caráter opressor da instituição total. As notas dos seminaristas eram simbolizadas por fitas de cores diferentes, com que se conseguia alguns privilégios. Do mesmo modo, nas aulas de Latim, o padre Lino separava seus alunos em dois grandes grupos, os "partidos", que deveriam desafiar um ao 
outro, disputando "um santinho" (FerreIrA, 1954/2008, p. 47). Esse processo de ensino gera uma competividade excessiva entre os alunos, o que prejudica a visão construtiva dos seus próprios erros e a formação de uma personalidade madura e equilibrada, pois eles passam a querer vencer a qualquer custo, preocupando-se só com os resultados e as premiações. Perde-se o valor do aprendizado em si.

Portanto, os inúmeros esforços dos alunos dos três colégios para se conservar dentro do regulamento e no topo das listas das notas não eram empregados somente a fim de zelar por uma boa imagem aos olhos da diretoria, mas, principalmente, para ter acesso às regalias relacionadas a tal imagem. Esse é um método educacional, de certo modo, ligado ao behaviorismo, pois intenciona moldar o comportamento dos alunos, fazendo-os mais interessados no estímulo (santinhos ou saídas-prêmio) do que na instrução. O objetivo de tratar a educação como moeda de troca é esvaziar o seu sentido. Isso casa com a seguinte observação:

Como num quartel, ou mesmo numa prisão, os alunos são submetidos a uma rotina rígida e previsível, ao respeito cego às hierarquias e às normas. Nesse ambiente, 'educar' é procedimento simples: consiste em punir e premiar aqueles que, respectivamente, não se submetem e que se submetem ao sistema disciplinar. Em instituições como essa, de violência surda e desconhecimento do outro, educar significa adestrar (GAGLIARDI, 2008, p. 19).

Esses três colégios não se dispõem a constituir seres críticos e autônomos, pelo contrário, adotam uma política que os determina "homens" brutos e alienados. Não por acaso, a educação formal desses alunos tem um lugar menor reservado dentro das narrativas. Em O Ateneu, os estudos apenas se tornam pauta do romance ao serem influenciados pelo estado de espírito de Sérgio frente ao embate diário com o meio e os demais. Por exemplo, é possível perceber que, quando se sente seguro e encorajado pelos colegas que lhe valem, isto é, Sanches, Bento Alves e Egbert, o protagonista se empenha no aprendizado de sua extensa lista de disciplinas e se sai bem nos exames internos e públicos. Nesse ponto, percebe-se, aliás, que Pompéia faz alusão e crítica à educação do Império, que tornou o ensino primário e secundário no Brasil um ensino conteudístico, tendo tomado por base as influências da pedagogia iluminista europeia (UnIVESP, 2010). Mais do que buscar formação enquanto cidadãos, os alunos eram educados a decorar tudo quanto possível para obter sucesso nas sabatinas de admissão ao ensino secundário ou ao ensino superior e para destacar-se da maioria ignorante do país. Santos (UNIVESP, 2010) comenta que é surpreendente como, em um ano letivo, os alunos conseguiam reter uma imensa carga de informações.

Quanto à trajetória de António, se o seu maior sonho na infância era ter acesso aos estudos, uma vez dentro do Seminário, menciona-se mais a extensa cadeia de rezas ao longo do dia, que mortifica e angustia o protagonista, do que a vontade de estudar o programa de disciplinas oferecido. Como em $O$ Ateneu, o estudo só 
é mencionado no romance quando se torna mote da interação ou, neste caso, do embate do protagonista com os demais, como quando o padre Tomás zomba da redação do protagonista, a qual julga possuir um vocabulário muito simples, impróprio de futuros sermões que, como ministro de Deus, proferirá. O padre o ridiculariza ao fazer alusão à sua baixa condição econômica, o que, além de expor e constranger o protagonista, torna-o inseguro sobre suas capacidades. Paralelamente, a cobrança dos tutores, responsáveis por sua educação formal, também é intensa. Segundo D. Estefânia, a caridade, que garantiria a dita celestial a ela, só tem valor se apresentar bons resultados. Quando António é convidado a jantar com a família dos tutores, vê-se em meio a uma difícil sabatina acerca de seus aprendizados gerais, lembrando-o do seu devido lugar na casa. Como observa Papoula (2009, p. 522), António "tem a ilusão de que também pode ter voz. Mas a verdade é que António continua indigno de diálogo. A condição de seminarista não o livra da imagem de menino pobre passivo da caridade da patroa". O menino termina a cena "confundido de sangue" (Ferreira, 1954/2008, p. 132). Nenhum de seus superiores ou responsáveis tenta compreendê-lo ou se preocupa realmente com sua formação humana.

Já em A Cidade e os cachorros, os cadetes não parecem muito comprometidos com as aulas, nem a memorização do conteúdo funciona. Shaw (1999, p. 141) indica que "El robo del cuestionario, que desencadena los demás episodios, resulta desde el principio de la novela totalmente irónico. Lo de menos son las clases de química o de cualquier otra asignatura. Lo que importa en el colegio es convertirse de 'perros' en 'hombres". Efetivamente, durante toda a obra, somente duas disciplinas são citadas. Além do roubo da prova de química, cuja menção tem o propósito único de trazer ação à trama, há a aula de francês - se é possível chamá-la de "aula" -, que somente visa mostrar a falta de respeito e interesse dos alunos frente aos professores e ao objeto de estudo. Nesse ambiente, a instrução básica formal fica relegada a segundo plano.

Assim sendo, está justificada a ironia da máxima que figura nas paredes do Ateneu, "Nenhum mestre é mau para o bom discípulo" (POMPÉIA, 1888/2008, p. 68). Ela revela a tentativa dos dirigentes de camuflar a arbitrariedade e a ineficiência do sistema, para se eximirem de culpa. E, para os demais discípulos, aqueles considerados ruins, há os castigos e as punições determinados pelas tais "regras da casa". Em Manhã submersa, os castigos para quem descumprir o regulamento são variados, mas, em geral, são públicos, para que sirvam de exemplo. Na primeira vez em que António presencia uma punição, o aluno é obrigado a ficar ajoelhado rezando o restante do dia. Quanto aos castigos dirigidos ao António, além de repreensões verbais, ora o padre Tomás lhe arranca a fita de boa nota do pescoço, ora o padre Lino, após exigir que António peça perdão de joelhos, aplica-lhe o castigo físico da palmatória, sendo que essas duas punições ocorrem diante dos outros alunos. Porém, a punição mais temida era a expulsão. Para relembrar os seminaristas disso, repete-se, sempre como o primeiro ponto da meditação, outra má- 
xima disciplinar intimidadora, própria do Seminário católico: "Muitos são os chamados, poucos os escolhidos" (FERREIRA, 1954/2008, p. 22).

Aristarco, como alegoria da figura do real Barão das Macahubas (Abílio César Borges), cria um sistema educacional próprio para o ensino primário no Brasil Império, que remete àquele que foi chamado, por Borges (1884), de "Lei nova do ensino infantil". Segundo essa lei, baniam-se "os deprimentes e humilhantes meios disciplinares e as penosas e brutais punições, que aos meninos tornam tão antipáticas e odiosas as escolas" (BorgEs, 1884, p. 6). Ao invés de castigos físicos, afirmavase tentar todos os meios para tornar o estudante um entusiasta por conhecimento, pois, sem vontade, não se aprende. Se não são empregadas punições físicas, é certo que, no Ateneu, continuam havendo punições dentro daquele sistema de privilégios determinado pelo arbitrário senso de justiça dos dirigentes. Assim, essa pedagogia permanece sendo uma medida disciplinar. Quando Sérgio e Franco são pegos pulando o muro do pátio e mentem ter ido colher sapotis, Aristarco marca um número de páginas a ser escrito à noite, e "adicionou-se a observação suplementar: passaríamos, os delinquentes, no outro dia, as horas do almoço e do jantar, ao refeitório, de pé, carregando em cada mão quantos sapotis coubessem" (PoмpéiA, 1888/2008, p. 110). Mesmo porque a punição deve vir a público como mau exemplo, como em Manhã submersa. Além dessas medidas mais usuais, para os desvios mais graves, Aristarco mantinha a "cafua", um ambiente escuro, sujo e degradado, que nada tem a ver com o modelo de instrução baseado na máxima "Mens sana in corpore sano", que Valdez (2012) revela ter ditado a vida dos colégios adeptos do modelo da "Lei nova do ensino infantil". Segundo a pesquisadora, essa era uma racionalidade médica-higiênica adotada pelas escolas privadas como forma de política atrativa, dadas as más condições de higiene do Rio de Janeiro e das principais cidades brasileiras em fins do Império. Porém, parece que, só na fachada do Ateneu, a máxima é cumprida à risca. Aos maus alunos, a punição imposta é tão dolorosa quanto os humilhantes e brutais métodos antigos que diz combater.

Em A Cidade e os cachorros, os castigos não diferem muito. A qualquer ato que vá contra o regulamento, os alunos perdem a saída do domingo. E ainda alguns castigos físicos dolorosos são empregados, como quando do atraso excessivo na fila de formação a cada manhã. Os três cadetes mais atrasados deveriam, no caso, escolher entre dois tipos de castigo, que denunciam extrema brutalidade por parte dos tenentes: o "ângulo reto" ou o "seis pontos". Os oficiais se valem de sua hierarquia para impor quaisquer punições, mesmo aquelas que humilhem, firam e exponham os alunos. Ademais, como em O Ateneu, para os casos mais graves, há uma prisão degradante, caracterizada como um espaço escuro, pequeno, sem ventilação ou mínimas condições de higiene. Porém, conforme lembra Goffman (2010, p. 71), a manutenção de "padrões humanitários passa a ser definida como parte da 'responsabilidade' da instituição e, presumivelmente, como uma das coisas que a instituição garante ao internado, em troca de sua liberdade". 
$\mathrm{Na}$ abertura do romance de Llosa, já fica declarado que o estado de degradação do colégio, revelada principalmente pelo aspecto imundo dos dormitórios e dos banheiros, difere dessa ideia de "responsabilidade" que a diretoria deveria ter para com o seu material humano. No entanto, esta não é a imagem que o colégio passa à sociedade. Ele é vendido para o mundo externo como um clube de férias, pretendendo-se até um espaço utópico. No folheto do Leoncio Prado, constam "campos de futebol, uma piscina límpida, cantinas, dormitórios desertos, limpos e arrumados", além de "uma fotografia colorida [que] mostrava uma formação de linhas perfeitas desfilando diante de uma tribuna" (LLOSA, 1963/2007, p. 196), o que difere bastante do cotidiano do colégio militar, mas convence o pai de Escravo. Começa a ficar nítida, então, a disparidade existente entre a educação de transparência que se vende e a educação de opacidade que se compra, citando Bosi (1988). Nas primeiras visitas ao Ateneu, por ocasião das festas de encerramento letivo e de ginástica, Sérgio e seu pai também ficam maravilhados com a propaganda que se faz sobre a eficiência do ensino e a ordem do colégio. Por sua vez, a António, nem é dada a oportunidade de escolher uma escola encantadora, na qual gostaria de estudar. Embora o internato lhe desagrade logo nos primeiros dias, por ordem do reitor, ele escreve cartas à mãe elogiando o Seminário escolhido pela tutora, perpetuando, assim, o prestígio do estabelecimento.

\section{Marketing: a educação como mercadoria}

O enfoque dado, em $O$ Ateneu, à propaganda, é o maior dentre os três romances. Logo no primeiro capítulo, o narrador elege Aristarco a "homem-sanduíche da educação nacional" (PoмpéiA, 1888/2008, p. 58). Santos (2000) mostra que, na época do Segundo Reinado no Brasil, o sistema educativo atingia apenas uma reduzidíssima parte da nação: "as escolas primárias chegavam a $2 \%$ da clientela escolar". Como a classe mais privilegiada do meio carioca não somaria o número de alunos do Ateneu, um colégio privado, Aristarco tinha de manter bons contatos em todo país e se orgulhava em dizer que só entrava no Ateneu a "fina flor da mocidade brasileira" (РомpéiA, 1888/2008, p. 45). Além disso, a partir da lei que sancionou a liberdade da iniciativa privada em 1823, o número de escolas particulares no país superou a escola pública. Santos (2000) mostra que começou a circular uma crença de que a escola privada havia vindo para libertar o ensino público, visto que se cultivava o hábito de atender gratuitamente alguns meninos pobres. Porém, esses meninos recebiam tratamento diferenciado, jamais lhes eram concedidos os mesmos direitos dos alunos pagantes. E a caridade só era tida como válida quando podia ser exibida - semelhante ao que pensa D. Estefânia no romance português. Assim, no Ateneu, "os professores tinham a obrigação de os fazer brilhar” (POMPÉIA, 1888/2008, p. 178). Essa ação social era interessante porque acabava por contribuir para a boa imagem do colégio e, na perspectiva de Aristarco, a máquina pedagógica é máquina de fazer dinheiro. 
Contudo, grande parte dos problemas dessas instituições reside justamente no fato de se tratar a educação como mercadoria. Até mesmo entre os ditos pagantes, Aristarco fazia distinção. Por exemplo, dispensava tratamentos diferentes aos filhos de políticos influentes ou nobres e aos filhos de inadimplentes: "Sua diplomacia dividia-se por escaninhos numerados [...]. Ele tinha maneiras de todos os graus, segundo a condição social da pessoa. As simpatias verdadeiras eram raras" (PompÉIA, 1888/2008, p. 60). A recepção ao protagonista, durante a matrícula, foi das melhores, levando a crer que o pai de Sérgio não passava dificuldade econômica. No entanto, o aluno mais invejado do Ateneu era Rômulo, o qual, "ancho de fortuna" e considerado "bom partido" (PoMpéiA, 1888/2008, p. 173), Aristarco queria por genro, oferecendo-lhe vários privilégios no colégio, como o cargo de vigilante, banquetes exclusivos e, principalmente, o direito à inimputabilidade, como a ausência de castigo nos casos do seu erro no manejo do bombo, que provocou riso geral da plateia durante um desfile da banda, e do flagrante da sua fuga ao jardim. Torna-se interessante notar que Aristarco chegou ao seu favorito porque ele também tocava o bombo, um dos instrumentos "prediletos porque gritava mais!" (PoMPÉIA, 1888/2008, p.175), ou melhor, porque chamava mais atenção para o nome do colégio. No Seminário, da mesma forma, há uma banda própria, para propaganda da casa. Segundo António, que tocava caixa ao lado de Peres, do bombo, o papel de quem toca esse instrumento é mesmo de destaque, "ocupava o centro da pancadaria, na vanguarda da filarmónica, e isso dava-lhe uma grandeza de condutor" (FERREIRA, 1954/2008, p. 119).

Todo mecanismo de controle desses internatos é guiado pelos princípios do marketing. Assim, em geral, não há punição para aqueles casos de violação do regulamento que não vêm a público ou que não chamam a atenção dos inspetores. À bem da verdade, a educação só se mostra efetiva quando há a preocupação com a opinião pública. Em $O$ Ateneu, se, por um lado, Sérgio não chega a ser punido quando agride o diretor fisicamente, porque Alves já tinha se retirado do colégio e, então, Aristarco não se arrisca a perder dois alunos de uma vez só - "soldavam-se nele o educador e o empresário" (PompéiA, 1888/2008, p. 59); por outro, Aristarco é obrigado a ser rígido quando os próprios alunos denunciam a "imoralidade", como no caso do namoro de Cândido Lima e Emílio Tourinho. Ironicamente, no mesmo dia, ocorre a revolução da "goiabada de bananas", na qual os alunos decidem gritar injúrias à instituição e atirar o jantar uns aos outros, alegando terem sido enganados até na sobremesa, feita com bananas moles. Aristarco reflete "expulsar... expulsar... falir talvez" (PompÉIA, 1888/2008, p. 202). Por fim, resolve deixar de lado as doutrinas disciplinares para entrar no saguão com ar manso, de quem se rende, preferindo dar razão ao tumulto dos alunos do que perder mensalidades.

Em Manhã submersa, durante um ensaio da banda, o padre Martins surpreende António e Peres conversando, o que configura um delito, visto que são seminaristas de divisões diferentes. Porém, há ainda um segundo e mais grave delito, $\mathrm{Pe}-$ res estava entregando ao protagonista uma revista pornográfica. Como o padre fala alto para recriminá-los, chamando a atenção dos presentes, torna-se neces- 
sário uma punição exemplar ao caso de "imoralidade" que veio a público. Contudo, como no Ateneu, o Seminário não pode perder duas mensalidades de uma só vez. António passa pela humilhação da retirada das fitas de boa nota na frente de todos, enquanto Peres é expulso. Apesar de haver punição, não há qualquer orientação aos alunos, porque um sermão ou conselho qualquer tangeria um assunto proibido aos seminaristas, e essa atitude de colocar "panos quentes" sobre o ocorrido só contribui para aumentar a tensão sexual pela qual os alunos estão passando. Quando conversa com padre Alves - um dos únicos superiores que parece dar atenção aos problemas individuais dos seminaristas e querer aconselhálos verdadeiramente -, António descobre que foi salvo por ser o mais novo. Também é salvo porque já havia acontecido, pelo menos, outras três expulsões recentes. O reitor deve pensar como Aristarco, "expulsar... expulsar... falir talvez".

A filosofia pedagógica dos colégios dos três romances se aproxima por este discurso de combate à imoralidade e à desordem, apresentando-os como igualitários, justos e livres, porém, apenas na aparência, eles constituem uma instituição "que não opõe obstáculos ao olhar do cidadão comum [e que] proporciona uma visibilidade plena dos mecanismos de seu funcionamento" (Muricy, 1988, p. 479). Não é de interesse dos dirigentes gastar energia e, ao mesmo tempo, pôr em risco um amplo negócio financeiro em favor da rígida formação humana, pautada na transmissão de valores e na orientação dos problemas individuais dos alunos, em prol de uma educação mais eficaz. Em O Ateneu, quando Franco morre, por causa dos maus cuidados do diretor, Aristarco fica abatido e chora. Contudo, "não convinha ao colégio o aparato de um grande enterro, pregão de insalubridade" (PompÉIA, 1888/2008, p. 233).

Em A Cidade e os cachorros, os administradores também sabem optar sempre pelas decisões que lhe são mais convenientes, como quando afirmam categoricamente a morte acidental do Escravo. O coronel dá pessoalmente as instruções sobre a ordem do dia que circulará na sociedade: "Especifique que tudo foi causado por um erro dele mesmo [do morto]" (LLOSA, 1963/2007, p. 224). Mesmo cientes de que houve um assassinato doloso no colégio, pois têm em mãos o laudo médico, que garante que "a bala veio de trás" (LLOSA, 1963/2007, p. 227), os oficiais escolhem a explicação que é melhor para a sua reputação como educadores e militares, não o que seria melhor para os alunos. Para seguir os protocolos sociais e se dizer solícito, o coronel convoca uma reunião com sua equipe e lhe ordena que seja providenciado um funeral cheio de pompa e um discurso enaltecendo o cadete morto aos familiares. Dessa forma, Escravo se torna "um cadete brilhante" (LLOSA, 1963/2007, p. 236). O coronel ainda afirma que é importante todos lamentarem o ocorrido e reiterarem que, no Exército, só quem comete erros pode se dar mal, instruindo, assim, os demais internos a tomar cuidado e induzindo-os a não desconfiar do crime.

A mesma postura dos dirigentes é registrada em Manhã submersa. Quando Gaudêncio morre, também por negligência dos dirigentes do colégio, que não conse- 
guem dar assistência a todos os alunos durante a epidemia de gripe, o reitor faz uma grandiosa cerimônia de liturgia dos mortos e reúne os seminaristas para um discurso no qual ele, como a autoridade máxima naquele mundo, resolve mudar a História, "fez enfim um espantoso elogio das virtudes do Gaudêncio" (FERreira, 1954/2008, p.180), oferecendo-lhe até um retrato. Uma vez que ele morreu sob os cuidados dos padres, o que se tinha a fazer era apagar suas falhas, a fim de tentar minimizar os problemas e tirar proveito da situação instruindo os demais internos para uma boa conduta. Assim, Gaudêncio também se tornou "um seminarista modelar" (FERREIRA, 1954/2008, p. 180).

\section{O olhar hierárquico e autoritário dos dirigentes}

Há um empenho constante na proteção das figuras dos dirigentes, para que se mantenham como autoridades máximas e absolutas. Em O Ateneu, Aristarco, bem ou mal, domina o colégio. Ele consegue atingir seu objetivo de ser respeitado pelo temor: "um simples olhar do diretor imobilizava o colégio fulminantemente, como se levasse no brilho ameaças de todo um despotismo cruento" (PompéiA, 1888/2008, p. 104). Desde o início do romance, há uma divinização em torno de Aristarco, que vende sua imagem juntamente à imagem do colégio: "A uma delas [das janelas centrais do prédio], Aristarco mostrava-se" (PoMPÉIA, 1888/2008, p. 54). Como esclarece Goffman (2010), o funcionário de mais alto nível torna-se o símbolo do estabelecimento, por isso se veste bem, sorri e demonstra um interesse paternal pelos internos, como quem exige reverência e submissão deles. Aristarco age exatamente assim, quer-se "pai", para, aos poucos, conquistar a posição de "Providência Divina" (PoMPÉIA, 1888/2008, p. 92).

Considerando o caso de Manhã submersa, Júlio (1996, p. 47) comenta sobre "o terror personificado colectivamente no corpo dos Prefeitos e individualmente no Reitor, como figurações do terror divino”. Quando António chega ao Seminário, ao entardecer, depara-se com um ambiente escuro, onde vários padres, descritos como "mudos e quedos" (Ferreira, 1954/2008, p. 19), posicionam-se estrategicamente ao longo do corredor a fim de exercer uma vigilância absoluta e o controle dos movimentos dos internos. Ainda segundo o protagonista, "na pura ameaça de seu olhar de sombra eu sentia, mais escura, a grandeza ilimitada de um pavor abstracto" (FERreIrA, 1954/2008, p. 19). A falta de luz, o silêncio e a presença constante dos padres são mecanismos moldados para estabelecer o medo, um "pavor abstracto" e "ilimitado", ou seja, um sistema de coerção. Segundo Santos (2009, p. 69), "essa sensação de vigilância pesada [...] indica a metáfora de um poder ditatorial e de sua polícia que agia durante a noite, sem deixar traços". O olhar dos Padres Prefeitos é um olhar intruso, que tira a liberdade e autonomia de quem é olhado.

Nesse sentido, as considerações de Foucault (1975) sobre o panoptismo são esclarecedoras. O panóptico, inventado por Jeremy Bentham, é uma estrutura arquitetural de cerceamento e controle, a qual tem o formato de anel com uma torre no meio. Nesse anel, ficam várias celas e na torre, vigias. Assim, o panóptico foi cri- 
ado para fiscalizar as ações isoladas de um grande número de pessoas, de maneira que quem é visto nunca vê e quem vê nunca é visto, tornando sutis as formas de controle. O propósito de Bentham era induzir o internado a um estado consciente de sua permanente visibilidade, de modo que, mesmo se a observação fosse descontínua, seus efeitos se tornassem permanentes, ou melhor, de modo que esse internado não se arriscasse a cometer faltas.

O panóptico consiste, então, em vigilância, controle pelo olhar. Por outro lado, como afirma Spíndola (2010, p. 87), "o panoptismo inventado por Foucault consistiria em perceber como esse panóptico é indicativo de uma percepção social”. Spíndola (2010, p. 14) nota ainda que "a observação contínua serviria para disciplinar, sendo esse modelo aplicado à sociedade como um todo, na forma daquilo que o mesmo [Foucault] chamou de 'docilização dos corpos' [...], isto significa dizer que os métodos disciplinares contribuíram para formar uma sociedade obediente”. Assim, o modelo de poder designado para o panóptico passa a ser uma nova concepção política adotada pelas sociedades modernas e suas diversas instituições, como os colégios internos.

Santos (2009, p. 69) também lembra que "a primeira aparição do reitor do Seminário é emblemática da dominação progressiva dos seminaristas”. Para António, ele realmente era "o símbolo mais perfeito do terror" (FerreIRA, 1954/2008, p. 32). Todas as aparições do reitor são controladas, como seus gestos e suas falas, de modo a levar os alunos, então intimidados, a concordar com aquele sistema de poder autoritário que não permite ser questionado e os induz à alienação. E, se o reitor não está presente em pessoa, faz com que os alunos o sintam presente no olhar dos Padres Prefeitos, os quais garantem o que Goffman (2010) chama de "autoridade escalonada”. É possível perceber que esse regime autoritário cumpre a sua função quando o silêncio empregado por aqueles que estão no topo da escala hierárquica do Seminário, ou seja, o silêncio dos padres e do reitor, passa a silenciar os alunos internos, a quem não é dada a chance de se expressar. Conforme Papoula (2009, p. 519), "sob a constante vigilância de um 'olho aberto em cada salão', os sentimentos de medo e solidão mantiveram inibida qualquer emissão de som [por parte de António]". De fato, as palavras "silêncio" e "olhar", que configuram os dois principais elementos coercitivos dessa instituição total, repetem-se constantemente ao longo do romance.

Já em A Cidade e os cachorros, o coronel raramente é visto e pouco ou nenhum contato tem com o estabelecimento e os internos, entretanto sua figura, de modo simbólico, também paira acima das cabeças dos alunos exigindo obediência ao regulamento. Além dele, o tenente Gamboa, o mais alto posto em contato direto com os meninos, é respeitado e temido: "Olhou um instante para nós e disse: 'sentido!', [...] em menos de um segundo estávamos em forma" (LLOSA, 1963/2007, p. 157). Porém, Gamboa é exceção entre o grupo de dirigentes do romance, ele é o único que leva as "regras da casa" a sério, empregando uma vigilância mais acirrada e cumprindo as normas à risca. Por isso, é ele quem descobre e pune o Círculo. Os 
demais oficiais não se interessam por manter um sistema de controle ativo, pois não demonstram o mínimo interesse pela educação dos alunos, mas, ainda assim, exigem respeito à própria figura.

A partir do momento em que a política de proteção à imagem do estabelecimento e de suas autoridades máximas passa a valer mais do que o compromisso educacional, muito do desregramento fica sem a devida atenção e punição. Não deixa de haver, no Seminário, os padres vigilantes; no Leoncio Prado, chefes de turma e sentinelas noturnas; e alunos vigilantes e inspetores no Ateneu, assegurando o papel de "autoridade escalonada"; entretanto, os mecanismos de controle, nas três instituições, são mais intimidadores do que propriamente eficazes. Por exemplo, no Seminário, os inspetores não conseguem controlar as fugas; assim como, no Ateneu, não conseguem controlar os namoros; e nenhum dos oficiais do Leoncio Prado sabe quem atirou em Escravo. Os responsáveis pela vigilância sequer são capazes de perceber e conter a mistura e conversa suspeita das séries escolares. Na natação do Ateneu, "o descuido da fiscalização permitia que as turmas se confundissem e o inspetor de serviço vigiava afastado, de sorte que ficavam expostos os mais fracos aos abusos dos marmanjos" (POMPÉIA, 1888/2008, p. 77). Com a importância conferida ao renome do colégio e de seus dirigentes, a vigilância passa a ser eventual. Cabe aos dirigentes decidir, ao final, o que foi ou não visto, pois não interessa trazer todos os desvios do regulamento à tona.

\section{A conformação do espaço}

Após serem "atirados para a luta" de sobrevivência no internato pela própria família, para que alcancem maturidade e hombridade, esses protagonistas adentram uma instituição escolar totalizante e disciplinar, que não hesita em empregar todos os meios para retirar sua autonomia e seu senso crítico. Além do mais, nem as medidas disciplinares em si mesmas, são seguidas propriamente, deixando que uma política de propaganda decida quando alguma atitude deve ser considerada digna de atenção por parte dos dirigentes. Caso seja considerada a perspectiva desses alunos, verificar-se-á que, quando entram para o confinamento, são tomados, em primeiro lugar, pelo sentimento de abandono causado pela mudança de ordem interacional e, depois, pelo sentimento de desamparo causado pela postura autoritária e arbitrária dos administradores dos colégios. Em pouco tempo, veemse totalmente entregues à própria sorte. António narra: "espoliado abruptamente da minha infância, sentia-me aturdido de angústia e solidão [...] E uma saudade densa caiu-me, como um peso, na alma" (FerreIrA, 1954/2008, p. 13). Também Sérgio pressente-se sozinho, acha-se "perdido" desde o primeiro dia, quando afirma estar em meio a uma "caixa desmedida de paredes" (PoмPÉIA, 1888/2008, p. 71).

A formação desses jovens protagonistas se inscreve, portanto, em caráter cronotópico. Considera-se aí o conceito do "cronotopo" como a expressão de indissolubilidade de espaço e de tempo. Em O Ateneu, conforme explica Cruz (2010, p. 68), "a estrutura do colégio é a de um edifício construído num quadrado mu- 
rado, com um pátio central e diversos pavimentos, inclusive alguns independentes [...], o que reitera a questão do confinamento, da limitação". O colégio apresenta mesmo a configuração de uma "caixa desmedida de paredes", fazendo o tempo se mover em um espaço fixo. Surge, assim, o que Cruz (2010, p. 68) chama de "claustrotopia”, isto é, um saber de detento na cela, uma experiência de claustro que depende do modo como cada indivíduo percebe o tempo discorrer dentro desse espaço. Em A Cidade e os cachorros, não é diferente, pois o colégio fica dividido entre três grandes blocos de cimento, que servem de alojamentos aos cadetes, além do espaço do pátio e outras estalagens.

Quanto a Manhã submersa, como explica Laso (1989, p. 151), “desde o começo da história, e progressivamente, o edifício do seminário deixa de ser um centro de educação para ser algo de ameaçador [...]. O seminário personifica-se até em gigante, monstro ou colosso", como na cena em que António avista pela primeira vez o prédio do colégio. Mesmo por dentro, ele não lhe parece mais acolhedor. Apavoram António os longos corredores, seus janelões soturnos, sua escuridão, seu odor e ele completa: "esmagava-me o silêncio, o frio dos tectos altos, o peso das traves enormes" (FerreIra, 1954/2008, p. 36). Em meio a esse ambiente, o protagonista começa a ser tomado por um forte sentimento de angústia e de solidão, que vai se agravando à medida que toma consciência dos coercitivos mecanismos de funcionamento que regem a instituição, até ao ponto que decidirá retomar seu poder de ação, ou seja, seu poder de controle sobre a própria trajetória de vida.

Ao adentrarem nesses internatos escolares, os protagonistas dos três romances são submetidos a um mecanismo educacional que, por ter base na teoria disciplinar, se utiliza da medida da vigilância panóptica, uma rotina de exercícios exaustivos e leis próprias de premiação e punição, a fim de induzi-los a um tal estado de alienação que aplaque sua capacidade de diferenciação e contestação. Os dirigentes dessas instituições não parecem se importar em garantir uma formação integral aos alunos, desejam antes que sejam "adestrados". Desse modo, a prioridade passa a ser a de assegurar a imagem do colégio e, acima de tudo, os seus próprios interesses. No início, os protagonistas se sentem completamente mortificados, tomados pelos sentimentos de angústia e de solidão. Porém, ao longo das narrativas, dentre os conflitos que estabelecem com o meio e os demais, e por serem heróis de romances, vão adquirindo certo entendimento sobre esses mecanismos coercitivos que regem o ambiente no qual estão inseridos, os quais visam uniformizar o comportamento de todo um segmento social pela repressão e pelo medo. Resta observar como os heróis conseguirão retomar sua autonomia, seu posicionamento crítico e sua liberdade.

\section{Referências}

Almeida, Bruna Gisi Martins de. A experiência da internação entre adolescentes: práticas punitivas e rotinas institucionais. 2010. Dissertação (Mestrado em Sociologia) -Universidade de São Paulo, São Paulo, 2010. 
BenElli, Silvio José. A instituição total como agência de produção de subjetividade na sociedade disciplinar. Estudos de Psicologia, Campinas, v. 21, n. 3, p. 237-252, set./dez. 2004. Disponível em: http://www.scielo.br/pdf/estpsi/v21n3/ v21n3ao8.pdf. Acesso em: 05 maio 2019.

Borges, Abílio César. A nova lei do ensino infantil pelo Barão de Macahubas. Bruxelas: Typographia e litographia E. Guyot, 1884.

Bosi, Alfredo. O Ateneu, opacidade e destruição. Céu, Inferno: ensaios de crítica literária e ideológica. São Paulo: Ática, 1988. p. 33-57.

Cruz, Ana Carolina de Picoli de Souza. O Ateneu, uma claustrotopia: espaço de discursos modeladores. 2010. Dissertação (Mestrado em Estudos Literários) - Universidade Estadual Paulista, São Paulo, 2010.

Ferreira, Vergílio. Manhã submersa. Lisboa: Quetzal, 1954/2008.

Foucault, Michel. Vigiar e Punir: nascimento da prisão. Tradução de Raquel Ramalhete. Petrópolis: Vozes, 1987.

Gagliardi, Caio. Singularidades em Raul Pompéia: o homem, a escola, o romance. In: PompéiA, Raul. O Ateneu: crônica de saudades. São Paulo: Hedra, 1888/2008. p. 9-38.

Goffman, Erving. Manicômios, prisões e conventos. Tradução de Dante Moreira Leite. São Paulo: Perspectiva, 2010.

Júlıo, Maria Joaquina Nobre. O discurso de Vergílio Ferreira como questionação de Deus: ensaio interdisciplinar. Lisboa: Edições Colibri, 1996.

Laso, José Luís Gavilanes. Vergílio Ferreira: espaço simbólico e metafísico. Tradução de António José Massano. Lisboa: Dom Quixote, 1989.

LlosA, Mario Vargas. A Cidade e os cachorros. Tradução de Samuel Titan Jr. Rio de Janeiro: Objetiva, 1963/2007.

Muricy, Katia. Os olhos do poder. In: Novaes, Adauto (org.). O Olhar. São Paulo: Companhia das Letras, 1988. p. 479-486.

PApoula, Talita. Manhã submersa ou as vozes do silêncio: a propósito de um romance de Vergílio Ferreira. Revista Eutomia, Recife, v. 1, n. 3, p. 517-530, 2009. Disponível em: https://periodicos.ufpe.br/revistas/EUTOMIA/article/view/1904. Acesso em: 12 jul. 2019.

Pompéia, Raul. O Ateneu: Crônica de Saudades. São Paulo: Hedra, 1888/2008.

Quintale Neto, Flavio. Ideias estéticas e filosóficas nos romances O Ateneu, de Raul Pompéia, e Die Verwirrungen des Zöglings Törless, de Robert Musil. 2007. Tese (Doutorado em Letras) - Universidade de São Paulo, São Paulo, 2007. 
SANTos, Graça dos. O seminário, escola dos pobres, em Manhã submersa (1953), de Vergílio Ferreira. Comunicação \& Educação, a. 14, n. 3, p. 63-72, set./dez. 2009. Disponível em: http://www.revistas.usp.br/comueduc/article/view/43632/47254. Acesso em: 05 maio 2019.

SANTos, Manoel Isaú Souza Ponciano dos. Luz e Sombras: Internatos no Brasil. São Paulo: Salesianas, 2000.

SHAW, Donald Leslie. El Boom. In: SHAW, Donald Leslie. Nueva narrativa hispano americana: boom. posboom. posmodernismo. Madrid: Cátedra, 1999. p. 99-158.

Spíndola, Pablo. A arte e o ofício de historiar: Foucault e a invenção do panoptismo. 2010. Dissertação (Mestrado em História) - Universidade de São Paulo, São Paulo, 2010.

Univesp. No Império chega o ensino secundário. 13 jul. 2010. (9m56s). Disponível em: http://www.youtube.com/watch?v=mNMvgOHkDPA. Acesso em: o5 maio 2019.

VALDEZ, Diane. Mens sana in corpore sano: os colégios de Dr. Abílio César Borges, o Barão das Macahubas. História, Sociedade e Educação no Brasil. [on-line] Campinas, 2012. Disponível em: http://www.histedbr.fe.unicamp.br/navegando/artigos_ frames/artigo_o37.html. Acesso em: 05 maio 2019.

Recebido em 5 de maio de 2019.

Aprovado em 20 de outubro de 2019.

\section{Resumo/Abstract/Resumen}

O mecanismo educacional nos romances $A$ Cidade e os cachorros de Mario Vargas Llosa, Manhã submersa de Vergílio Ferreira e O Ateneu de Raul Pompéia

\section{Ana Carolina Rhormens de Santana}

\section{Caio Gagliardi}

Este artigo pretende analisar o mecanismo educacional implementado pelos internatos escolares de três romances - A Cidade e os cachorros (1963) de Mario Vargas Llosa, Manhã submersa (1954) de Vergílio Ferreira e O Ateneu (1888) de Raul Pompéia. O objetivo é examinar como as particularidades dos coercitivos métodos adotados pelos dirigentes dessas instituições podem ser tomadas como variações de um mesmo sistema de controle disciplinar, o qual, utilizando a medida da vigilância panóptica, uma rotina de exercícios repetitivos e exaustivos e leis próprias de premiação e punição, visa moldar o comportamento do interno, induzindo-o a um tal estado de alienação que aplaque a sua capacidade de diferenciação e de contestação. Prevê-se ainda explorar, mais especificamente, as implicações da postura autoritária e arbitrária dos educadores desses romances para a formação integral 
dos alunos protagonistas, uma vez que a prioridade parece ser a de assegurar a imagem do colégio e seus próprios interesses.

Palavras-chave: Raul Pompéia, Vergílio Ferreira, Vargas Llosa, educação, internato, instituição total, disciplina, panoptismo, repressão.

The Educational Mechanism in the boarding schools of Mario Vargas Llosa's The Time of the Hero, Raul Pompéia's O Ateneu and Vergílio Ferreira's Misty Morning

\section{Ana Carolina Rhormens de Santana}

\section{Caio Gagliardi}

This article analyzes the educational mechanism implemented by the boarding schools in three novels - Mario Vargas Llosa's The time of the hero (1963), Raul Pompéia's O Ateneu (1988) and Vergílio Ferreira's Misty Morning (1954). The main objective is to examine the particularities of the coercive methods employed by the leaders of these institutions. This paper considers if these methods may be taken as variations of the same system of disciplinary control, which, using panoptic procedures, a routine of repetitive and rigorous exercises and a particular method of reward and punishment, aims to define the students' behavior, inducing them to such a level of alienation that assuages their autonomy and ability to question this system. The purpose of this paper also is to investigate, more specifically, the implications of the authoritarian and arbitrary attitude of these mentors for the protagonists' education, given that their priority seems to be to protect the school's image and their own interests.

Keywords: Raul Pompéia, Vergílio Ferreira, Vargas Llosa, education, boarding school, total institution, discipline, panopticism, repression.

El mecanismo educativo en las novelas La ciudad y los perros, de Mario Vargas Llosa, Manhã submersa, de Vergílio Ferreira y O Ateneu, de Raul Pompéia

\section{Ana Carolina Rhormens de Santana}

\section{Caio Gagliardi}

Este artículo tiene como objetivo realizar un análisis del mecanismo educativo empleado por los internados escolares en tres novelas: La ciudad y los perros (1963), de Mario Vargas Llosa; Manhã submersa (1954), de Vergílio Ferreira y O Ateneu (1888), de Raul Pompéia. El objetivo es examinar como las particularidades de los métodos coercitivos utilizados por los directores de esas instituciones pueden ser tomadas como variaciones de un mismo sistema de control disciplinario, el cual, utilizando la vigilancia panóptica, una rutina de ejercicios repetitivos y exhaustivos y sus propias leyes de premio y castigo; pretende determinar el comportami- 
ento del alumno, induciéndolo a un estado de alienación tal que reduzca su capacidad de diferenciación y de contestación. Pretendemos explorar, más específicamente, las implicaciones de la postura autoritaria y arbitraria de los educadores de estas novelas sobre la formación de los alumnos protagonistas, ya que la prioridad parece ser la de asegurar la imagen del colegio y sus propios intereses.

Palabras clave: Raul Pompéia, Vergílio Ferreira, Vargas Llosa, educación, internado, institución total, disciplina, panóptico, represión. 